\title{
Guidelines agreed for new social contract
}

The World Conference on Science closed in Budapest last Thursday (1 July) with 1,800 delegates from more than 150 countries agreeing on principles and guidelines for implementing what the organizers described as 'new social contract' between science and society.

Included in the specific suggestions were that countries should provide increased support for the networking of graduate and postgraduate institutions, that the training of scientific journalists and communicators should be enhanced, and that "adequate participatory mechanisms should be instituted to facilitate democratic debate on scientific policy issues".

One point of agreement was that 'ethics and social responsibility' should be an integral part of the education of all scientists. Existing panels in Unesco and the International Council for Science (ICSU), the coorganizers of the conference, have been given responsibility for following up on this issue.

Another proposal was that campaigns should be launched at national, regional and global levels to raise awareness of the contributions of women to science and technology, and that an international network of women scientists should be set up.

Both of these ideas figure among a set of recommendations intended to enhance the position of women in science that were adopted after vigorous lobbying by women's groups (see opposite).

The guidelines also encourage "special efforts" to ensure the full participation of disadvantaged groups - implicitly including the disabled - in science and technology. Such groups would be represented in policy-making bodies and forums.

The conference organizers had taken care to avoid explicitly committing participants to calls for any increased funding, not only from the industrialized to the developing nations, but also by developing nations themselves.

There was resistance to calls from some nations, in particular delegates from some Muslim states, that all countries should aim eventually to spend one per cent of their gross national product on research and development, a target that had been agreed at the last global science meeting, held 20 years ago in Vienna (see Nature 400, 8; 1999).

However, the final conference documents did agree in general that "innovative and cost-effective mechanisms" for funding science should be examined for implementation by "relevant institutions at the regional and international levels".

The conclusions of the six-day meeting were expressed in two documents, Declaration on Science and the Use of Scientific Knowledge, and Science Agenda: Framework for Action, known as the Declaration and Framework respectively.

Both were adopted unanimously by the final plenary session after several months of consultation with the member states of Unesco and other organizations, and a hectic two days of final drafting.

The first is a general statement of principles about the importance of science, as well as the need to respect a new 'contract' in which society pledges to continue to support science, while in return scientists agree to accept and respect their responsibilities.

The Declaration urges "the nations and the scientists of the world" to "acknowledge the urgency of using knowledge from all fields of science in a responsible manner to address human needs and aspirations without misusing this knowledge". It also says that helping to create a critical mass of national research in the sciences through regional and international cooperation is especially important for small states and least developed countries.

The second document is intended to provide guidelines through which the principles in the first document can be implemented by national governments, international organizations, professional scientific bodies indeed all those keen to promote a responsible relationship between science and society. Full text: http://helix.nature.com/wos/02-19.htm

\section{Conference a 'success' despite lack of support for global fund}

One way of establishing whether the World Conference on Science was a worthwhile event is to ask delegates whether they would go to another such gathering. In a straw poll conducted shortly after the end of the meeting, all of those questioned - from both rich and poor countries - replied without hesitation that they would.

Indeed, Lieutenant General Muhammad Noor Uddin Khan, minister for science in Bangladesh, said that such meetings should be held more often "and not every 20 years". Even members of the US delegation, often among the most sceptical participants, agreed that the conference had been worthwhile.

US officials singled out for particular praise the fact that an international meeting of this kind had been organized jointly with a non-governmental organization, the International Council for Science (ICSU). "This has not happened before," said one official. "It shows that civil society can become part of the United Nations system. It's a new way of doing business. It could be a model for future meetings."

For delegates from the developing countries, the conference provided the rare opportunity of direct access to key policymakers and heads of funding agencies from developed countries, as well as some insight into the unfamiliar world of international diplomacy. At the same time, however, there were some inevitable disappointments.

The delegation from Bangladesh, for example, in common with those from many developing countries, returned home disappointed at the lack of agreement on a new global fund for science. Many delegates from poor countries had come to Budapest genuinely believing that such a fund might be agreed upon.

Some delegations from developing countries also voiced criticism of what they considered to be inadequate preparation for the conference. They expressed concern at the absence of official preparatory meetings, usually an important feature of UN conferences.

Such meetings provide countries with a formal mechanism to comment on draft documents. Perhaps more importantly, they are occasions on which groups of countries can forge alliances around common demands. Indeed, it is often at preparatory meetings that the seeds of potential conflict with the developed world are first sown.

But the conference itself passed off relatively cordially. One reason was the absence of a strong developing country alliance. Perhaps another reason, according to a delegate from Senegal, was that many developing country delegates - who were drawn mainly from science ministries had never been to an international meeting of this type, and therefore lacked the requisite diplomatic lobbying and language skills. 